\title{
Endonasal Dacryocystorhinostomy; the learning curve and our experience
}

\author{
İsmet Emrah Emre' ${ }^{1}$ iD , Ali Rıza Cenk Çelebi ${ }^{2}$ iD
}

${ }^{1}$ Acıbadem Mehmet Ali Aydınlar Üniversitesi, Tıp Fakültesi, KBB-BBC ABD, İstanbul, Türkiye

${ }^{2}$ Acıbadem Mehmet Ali Aydınlar Üniversitesi, Tıp Fakültesi, Göz Hastalıkları, İstanbul, Türkiye

İsmet Emrah EMRE, Dr. Öğr. Üyesi Ali Rıza Cenk ÇELEBí, Doç. Dr.

Correspondence: Ali Riza Cenk Çelebi Acıbadem Mehmet Ali Aydınlar Üniversitesi, Tip Fakültesi, Göz Hastalıkları, İstanbul, Türkiye Phone: +902124044080

E-mail: arcenkcelebi@gmail.com

Received : 24 December 2019

Accepted : 23 April 2020

\section{ABSTRACT}

Aim: It was aimed to give an insight on the learning curve adopted by an ophthalmic surgeon while performing endonasal dacryocystorhinostomy under the supervision of an otolaryngologist with the results experienced during this survey.

Materials and Methods: In this retrospective study, consecutive cases with endonasal dacryocystorhinostomy (DCR) surgery were performed by a single ophthalmic surgeon while a second otolaryngologist was overlooking the procedures. A total of 29 surgeries were performed on 23 patients. Patients that were diagnosed with complete nasolacrimal duct obstruction were then evaluated and proceeded to the surgery. The intraoperative video was recorded in all surgical cases and recording time was noted for each case. All of the complications that occurred during or at the postoperative stages were noted.

Results: The mean age of the 23 patients was $55.25 \pm 18.6$ years $(15 y-80 y)$, of which 20 cases $(87 \%)$ were female. The left side was involved in $69 \%$ (20/29) of cases. At the final follow-up of the mean of 12,4 months, the anatomical and functional success was achieved in $89 \%$ (26/29) cases. The mean time spent in the operating theatre was $84 \pm 17.2$ minutes (range, $40-110 \mathrm{~min}$ ). It was found that the only 3 failed surgeries were in the first 5 surgeries performed with no surgical failure in the remaining 24 eyes.

Conclusions: Endonasal dacryocystorhinostomy is a safe, effective and cosmetically pleasing surgery for the treatment of nasolacrimal duct obstruction. Although it has a somewhat longer learning curve than some surgeries, once handling of the endoscope has been mastered and familiarity with the surgical field is improved, the duration of the surgery will decrease significantly. We believe multidisciplinary coordination plays an important role in decreasing potential complication rates and also in perfecting the technique.

Keywords: Endonasal Dacryocystorhinostomy, Ophthalmologist, Surgery Time, Learning Curve

\section{Endonazal Dakriyosistorinostomi; Öğrenme Eğrisi ve Tecrübelerimiz}

ÖZET

Amaç: Bu araştırma sırasında elde edilen sonuçlar ile bir kulak burun boğaz uzmanının gözetimi altında bir oftalmik cerrah tarafından gerçekleştirilen endonazal dakriyosistorinostomi operasyonunun öğrenme eğrisi hakkında bilgi verilmesi amaçlandı.

Hastalar ve Yöntem: Bu retrospektif çalışmada, endonazal dakriyosistorinostomi ameliyatı olan ardışık olgular, tek bir oftalmik cerrah tarafından ikinci bir kulak burun boğaz uzmanı gözetiminde gerçekleştirildi. 23 hastaya toplam 29 ameliyat yapıldı. Tam nazolakrimal kanal tıkanıklı̆ı tanısı konulan hastalar değerlendirildi ve ameliyat edildi. Tüm cerrahi vakalar intraoperatif olarak kaydedildi ve her vaka için kayıt süresi belirlendi. Postoperatif dönemde veya sonrasında meydana gelen komplikasyonların tümü kaydedildi.

Bulgular: 23 hastanın yaş ortalaması $55.25 \pm 18.6$ yı (15 yaş-80 yaş) idi; bunlardan 20'si (\% 87) kadındı. Sol taraf tıkanıkı̆̆ı vakaların \% 69'unda (20/29) yer aldı. Ortalama 12,4 aylık takip sonunda, \% 89 (26/29) olguda anatomik ve fonksiyonel başarı elde edildi. Ameliyathanede harcanan ortalama süre $84 \pm 17,2$ dakika idi (aralık, 40-110 dakika). Sadece 3 başarııı ameliyatın ilk 5 ameliyat arasında olduğu tespit edildi, geri kalan 24 vakada başarııızık saptanmadı.

Sonuç: Endonazal dakriyosistorinostomi, nazolakrimal kanal tıkanıkı̆̆ının tedavisi için güvenli, etkili ve kozmetik açıdan kabul edilen bir ameliyattır. Bazı ameliyatlardan biraz daha uzun bir öğrenme eğrisine sahip olmasına rağmen, endoskopun kullanımı ustalaştıktan ve cerrahi alanın aşinalığı geliştirildikten sonra, ameliyat süresi önemli ölçüde azalacaktır. Multidisipliner koordinasyonun potansiyel komplikasyon oranlarının azaltılmasında ve tekniğin mükemmelleştirilmesinde önemli bir rol oynadığına inanıyoruz.

Anahtar Sözcükler: Endonazal Dakriyosistorinostomi, Oftalmolog, Cerrahi Süre, Öğrenme Eğrisi 
D acryocystorhinostomy (DCR) was first described over 100 years ago (1) and is the treatment of choice for patients with nasolacrimal duct obstruction. In this surgery, the nasolacrimal duct is bypassed via an alternative tract formed between the lacrimal sac and the nasal cavity. It can be performed via an external or endonasal approach. Although the endonasal approach (2) was described earlier than the external technique, (1) it was not until the advent of the nasal endoscope (3) that the endonasal technique gained popularity. This was mainly due to the limited visibility of the surgical site and nasal anatomy during the endonasal approach. McDonogh first described the technique used today in 1989 (4). The major advantages of the endonasal approach are the absence of an external scar, the preservation of the orbicularis oculi pump action on the lacrimal sac and the avoidance of dividing the medial canthal ligament (5). However, this technique also has disadvantages including a higher equipment cost, a steeper learning curve, a smaller opening between the lacrimal sac and the nasal cavity and a higher recurrence rate (6). Both otolaryngologists and ophthalmologists have been adopting the endonasal approach more frequently with the advance in equipment made available for this surgery. In this study, we aim to show our results and also give an insight on the learning curve adopted by the novice ophthalmic surgeon (ARCC) while performing this surgery under the supervision of the experienced otolaryngologist (IEE).

\section{Materials and Methods}

\section{Study Design}

This was a retrospective study involving consecutive cases with surgery performed by a single surgeon (ARCC) with a second surgeon (IEE) overlooking procedures.

During the period between 2017-2019, a total of 29 surgeries were performed on 23 patients. All patients were evaluated for symptoms including excessive epiphora and recurrent eye infections. All patients were first evaluated by an ophthalmologist and a dacryoscintigraphy was performed for each patient. Patients who were diagnosed with nasolacrimal duct obstruction were then evaluated by an otorhinolaryngologist prior to surgery. Patients were examined for the presence of any anatomical obstruction that could have hindered the endonasal DCR including septal deviation, turbinate hypertrophy or concha bullosa. An informed consent was obtained from each patient regarding every aspect of the surgery.

\section{Surgical Procedure}

All surgeries were carried out in a supine position under general anesthesia. Before the beginning of surgery, cotton pledges soaked in $0.05 \%$ oxymetazoline were placed in the nasal cavity and between the middle turbinate and lateral nasal wall. These pledges were removed after 5-10 minutes and the lateral nasal wall mucosa was then infiltrated with local anesthetic (Jetokain $\mathrm{HCL} /$ adrenaline) under direct visualization with a rigid fiber-optic endoscope. $A$ reverse and upside -down $L$ incision was made on the mucosa with a horizontal $1.5 \mathrm{~cm}$ incision made from the anterior part of the attachment of the middle turbinate and a vertical incision made downwards towards the inferior turbinate. The mucosa was then elevated using a freer elevator and the bone medial to the lacrimal sac was fully exposed. We then removed the lacrimal bone with a high-speed drill and a combination of rongeurs. After the exposure of the lacrimal sac, we then infiltrated the sac with gel to facilitate easier removal of the medial wall of the sac. A vertical incision was placed in the sac and a large portion of the medial wall was removed. Bi-canalicular silicon tube insertion through both the upper and lower puncta was then performed and adequate opening of the sac was confirmed if both ends of the silicone tube passed freely through the opening. The silicone was then knotted in the nasal cavity.

\section{Results}

Twenty-nine endonasal DCR procedures were performed on 23 patients with a mean age of $55.25 \pm 18.6$ years ( 15 $y-80 y)$, of which 20 cases (87\%) were female. All cases had complete nasolacrimal duct obstruction (NLDO) confirmed with dacryoscintigraphy. The left side was involved in $69 \%(20 / 29)$ of cases. Three cases (13\%) required septoplasty (with sub-mucosal resection performed by IEE) at the time of DCR. Endonasal DCR in these cases were all successfully completed (ARCC).

The mean time spent in the operating theatre was $84 \pm 17.2$ minutes (range, 40-110 min). This included packing of the nasal cavity, local infiltration, surgery and early recovery. The intraoperative video was recorded in all surgical cases and recording time was noted. There were no intra-operative complications; however, postoperatively 3 patients (10\%) had significant adhesions between the lateral wall of the nose and nasal septum. Of the 3 failed cases, all underwent revision surgery with removal of adhesions.

Video analysis of the primary surgery highlighted inadequate exposure of the maxillary crest in the 2 failed cases 
which were both earlier cases in respect to this study. In the remaining one case, the posterior nasal mucosal flap was not fully retroplaced during removal of the maxillary crest. No significant bleeding occurred in that case. Revision surgery required removal of adhesions in 2 of the 3 cases and one case required granuloma excision. All revision surgeries were anatomically successful with complete recovery from symptoms.

Postoperative complications that were noted included mild epistaxis seen in 7\% (2/29) and stent prolapse, which was found in 3\% (1/29). Stent prolapse occurred 1 week following surgery and repositioning was done under endoscopic guidance in an outpatient facility. Stent extrusion was not noted. Ostium granulomas occurred in two cases and were managed conservatively in one with the use of topical steroids; the second case underwent revision surgery.

At the final follow-up of the mean of 12,4 months, anatomical and functional success was achieved in $89 \%(26 / 29)$ cases. Of the three cases that failed, the presenting diagnosis was recurrent chronic dacryocystitis.

\section{Discussion}

The endonasal DCR is a widely adopted, effective and safe treatment for nasolacrimal duct obstruction. However, there is no consensus on how to perform the surgery. There are multiple components that are still being debated today including the use of mitotic agents, the use of a silicone tube during surgery and the use of the laser to create an opening in the nasal cavity. Some surgeons prefer to apply antimitotic agents to decrease the incidence of granuloma formation, which is expected to be the major cause of surgical failure (7). A study by Qin et al (8) showed a significantly higher success rate in patients undergoing endonasal DCR who also had mitomycin C (MMC) applied during the surgery. However, Roozitalab et al found that the application of MMC was not beneficial in their study of external DCR (9). In our experience, we did not use any type of anti-mitotic agent and had 2 cases of failure due to granuloma formation. This rate of failure due to granuloma formation was similar to previous studies regarding failed endonasal DCR (7)

Another debatable subject is the use of silicone tubing during the surgery. The placement of a silicone tube through both puncta which is then knotted in the nasal cavi-ty has been proposed to decrease rates of failure. However, multiple studies have found this not to be true (10-12). In our study, we used silicone tubing in 28 of our cases and did not use tubes in only 1 patient. Our reason for this was because all patients had some degree of canalicular obstruction prior to surgery.

Although every surgery has a learning curve, the curve for this surgery is hindered by the inexperienced surgeons' lack of endoscope use. The otorhinolaryngologist is adapted to use the endoscope from the first day of residency; however, the ophthalmologist who does not perform endonasal DCR may never have used the endoscope in their career. In our study, we noted a slow decrease in the overall time for surgery until the 12th case. From this point onwards, there was a major decrease in surgical time which was attributed to improved handling of the endoscope and increasing familiarity with the surgical field (figure 1). Although a study by Onerci et al (13) stated a higher percentage of complications between experienced and novice surgeons, we found there to be no major difference in complication rates to previous studies performed by experienced surgeons. This we feel is the result of a multidisciplinary approach of two specialties dedicated to learning and teaching. Another study that looked into the training curve for endoscopic DCR showed a sharp decrease in operative time after the 27 th case (14). We also found there to be a sharp decrease after the 12th surgery that continued to decrease until the 29th surgery. Lee et al (15) showed an increase in positive surgical outcomes after 30 cases in their study. In our study, we also found that the only 3 failed surgeries were in the first 5 surgeries performed with no surgical failure in the remaining 24 eyes.

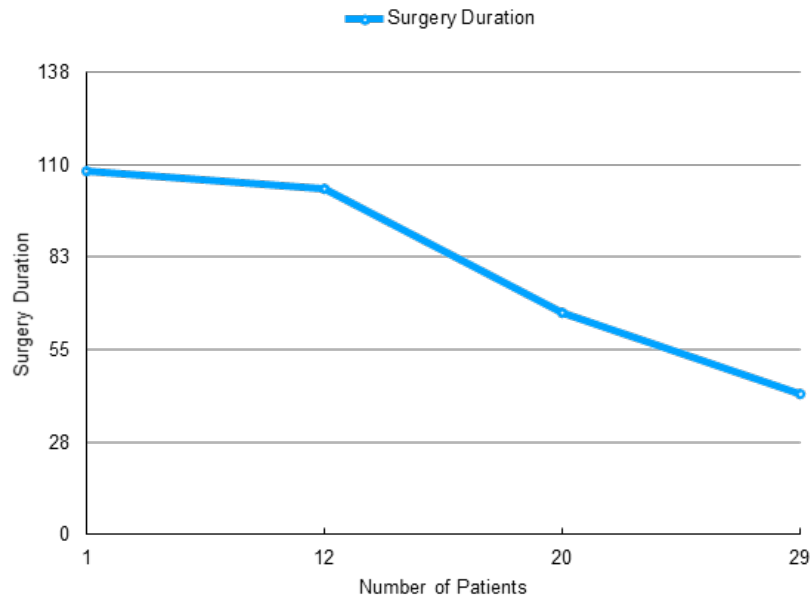

Figure 1: A chart depicting the decrease in the duration of the surgical session. Note the significant decrease in surgical time after surgery number 12 . 


\section{Conclusion}

Endoscopic DCR is a safe, effective and cosmetically pleasing surgery for the treatment of nasolacrimal duct obstruction. Although it has a somewhat longer learning curve than some surgeries, once handling of the endoscope has been mastered and familiarity with the surgical field is improved the duration of the surgery will decrease significantly. We believe that a multidisciplinary coordination plays an important role in decreasing potential complication rates and also in perfecting the technique.

\section{References}

1. Toti A. Nuovometodoconservatore di cura radicle delle suppurazonicroniche del saccolacrimale (Dacriocistorinostomia). Clin Mod Fir 1904; 10: 385-7.

2. Caldwell GW:Two new operations for obstruction of the nasolacrimal duct, NYJ Med 1893; 57: 581-2.

3. Stammberger H. Endoscopic endonasal surgery--concepts in treatment of recur-ring rhinosinusitis. Part I. Anatomic and pathophysiologic considerations. Oto-laryngol Head Neck Surg. 1986; 94: 143-7.

4. J McDonogh $\mathrm{M}$, Meiring JH. Endoscopic transnasal dacryocystorhinostomy. Lar-yngol Otol. 1989; 103: 585-7.

5. Hartikainen J, Antila J, Varpula M, Puukka P, Seppa H \& Grenman R. Prospective randomized comparison of endonasal endoscopic dacryocystorhinostomy and ex-ternal dacryorhinostomy. Laryngoscope 1998; 108: 1106- 13.

6. Jawaheer L, MacEwen CJ, Anijeet D. Endonasal versus external dacryocystorhi-nostomy for nasolacrimal duct obstruction. Cochrane Database Syst Rev. 2017;24(2):CD007097.

7. Baek JS, Jeong SH, Lee JH, Choi HS, Kim SJ, Jang JW. Cause and management of patients with failed Endonasal Dacryocystorhinostomy. Clin Exp Otorhinolaryn-gol. 2017; 10: 85-90.

8. Qin ZY, Lu ZM, Liang ZJ. Application of mitomycin C in nasal endoscopic dacryo-cystorhinostomy. Int J Ophthalmol 2010; 10: 1569-71.

9. Roozitalab MH, Amirahmadi M, Namazi MR. Results of the application of in-traoperative mitomycin C in dacryocystorhinostomy. Eur J Ophthal 2004; 14: 461-3.

10. Smirnov G, Tuomilehto H, Terasvirta M, Nuutinen J, Seppa J. Silicone tubing after endoscopic dacryocystorhinostomy: is it necessary?. Amer J Rhino 2006; 20: 600-2.

11. Unlu HH, Gunhan K, Baser EF, Songu M. Long term results in endoscopic dacryo-cystorhinostomy: is intubation really required?. Otolaryngology - Head \& Neck Sur-gery 2009; 14: 589-95.

12. Feng $Y F$, Cai JQ, Zhang JY, Han XH. A meta-analysis of primary dacryocystorhi-nostomy with and without silicone intubation. Can J Ophthalmol. 2011; 46: 521-7.

13. Onerci $\mathrm{M}$, Orhan $\mathrm{M}$, Ogretmenoğlu $\mathrm{O}$, Irkeç M. Long-term results and reasons for failure of intranasal endoscopic dacryocystorhinostomy. Acta Otolaryngol. 2000; 120: 319-22.

14. Kamal S, Ali MJ, Nair AG Outcomes of endoscopic dacryocystorhinostomy: Experi-ence of a fellowship trainee at a tertiary care center.Indian J Ophthalmol. 2016 Sep;64(9):648-653.

15. Lee JJ, Lee HM, Lim HB, Seo SW, Ahn HB, Lee SB. Learning Curve for Endoscop-ic Endonasal Dacryocystorhinostomy. Korean J Ophthalmol. 2017 Aug;31(4):299-305. 